\title{
Forming Children Character from View Person Centered and Al-Qur'an
}

\author{
Siti Rahmi, ${ }^{1}$ Urotul Aliyah, ${ }^{2}$ Nurul Fadilah ${ }^{3}$
}

\author{
${ }^{1}$ Guidance and Counseling Department, Universitas Borneo Tarakan, Tarakan, Indonesia \\ ${ }^{2}$ Guidance and Counseling Department, Universitas Borneo Tarakan, Tarakan, Indonesia \\ ${ }^{3}$ Guidance and Counseling Department, Universitas Borneo Tarakan, Tarakan, Indonesia \\ Corresponding Author*Email: rahmisitirahmi441@gmail.com
}

\begin{abstract}
The child's religious's mental, and moral development is not a process that can occur quickly and be forced. Still, it must be gradual, reasonable, healthy, and following the growth, abilities, and nature of the age that is being passed. Here, parents must be able to capture the positive trends of child development to be very important. Parents' obligation is to motivate and direct children to a positive outcome, even though the tendency is not following the parents' wishes. This, Islam teaches that in caring for children not to differentiate between boys and girls, eldest or youngest children, normal or abnormal children, parents still provide the same opportunity to obtain educational services following their potential, talents, and interests. Children must be treated fairly and not discriminatory. Hadith of the Prophet Muhammad says that "Educate your children (girls and boys), not according to your wishes, because they are children of their time." (H.R. Ibnu Majah).
\end{abstract}

Keywords: Children Character, Person-Centered Counseling, Al-Quran

\section{INTRODUCTION}

Children are a mandate entrusted by Allah SWT, Which must be cared for as well as possible by every parent. Since birth, children have been given various potentials that can be developed to support their life in the future. If these potentials are not considered, then in the future, children will experience obstacles in their growth and development. Therefore, character education for children is intended to instill values of kindness to become a habit when they become adults or at the next level of education. [1] [2] Character education for early childhood has a higher meaning than moral education because it is related to right-wrong issues and how to instil habits about various good behaviours to have children awareness and a commitment to practice virtue in everyday life.

[3] Allah SWT affirms in Surah Al-Balad, verse 17, that "then he is among those who believe and tell each other to be patient and tell each other to be compassionate. It is a valuable lesson for parents to treat and care for their children with love and patience. The hadith of Prophet Muhammad states every child is born in a state of nature, the two parents who make him Jewish, Christian, and Magi. (Narrated by Bukhari and Muslim).

The same thing is stated in person-centered counseling that humans tend to develop towards positive and constructive goals. Suppose respect and trust are upheld, which will be the climate of the family, school, and social environment. Therefore, children must be directed, motivated, instructed, punished, rewarded, and managed by others who are superior and expert, namely parents, educators, and society. [4] [5] P.C. counseling rejects parents' role as rulers and denies the capacity of children who only follow what parents dictate. [6] P.C. counseling is looking at children positively, which can be motivated because children have rational, social thoughts and can determine their destiny. Children can guide, regulate and control themselves. They only need to be provided with certain conditions. Thus, given the enabling conditions for growth and maturity, the child will fully develop to a certain extent. Parents' role is to 
see that children are creatures who essentially experience, feel, think, and contain many questions that have not been understood. Therefore, it is necessary to provide education with tolerance because life is an active process, not a passive process.

So, through P.C. and Al-Quran counseling and the hadiths above, it is said that in educating children, parents should not always use a culture of violence in childcare. Still, children are treated with love, without violating children's rights. Because by nature, children can be directed, motivated, instructed, punished, rewarded, and managed by others who are superior and expert, namely parents, educators, and society.

\section{METHOD}

This study uses a quantitative approach with a nonexperimental comparative research type to compare two variables in various conditions without any treatment for the variables to be studied. [7] [8] The basic design of comparative research involves selecting two groups of variables: the independent and dependent variables. In this study, the researcher wanted to compare two different variables, namely shaping the child's character from the point of view of person-centered (P.C.) counseling and Al-Quran, and without giving treatment to these variables.

\section{RESULT AND DISCUSSION}

\subsection{Person-centered (P.C.) counseling perspective in understanding children's character}

Human philosophy in the P.C. approach is a belief where humans have worth and dignity in themselves. Children deserve respect, have the capacity and things to organize themselves, get the opportunity, make wise judgments, and choose their values. According to the P.C. approach, children can learn to be responsible constructively, cope with their feelings, thoughts, and behavior. They have the potential to change constructively and develop towards an entire and satisfying life, or children can actualize themselves. Individuals can guide, organize, and control themselves to give a situation that allows for growth and maturity. The individual will fully develop to a certain extent, therefore through this P.C., the relationship between parent and child is significant. The key in building this relationship is the parent as a counselor and the counselor-counselee relationship or parent and child. [9] The P.C.'s emphasis on parenting is the warmth and acceptance of each child's uniqueness. It is further explained that the P.C. Approach views that humans tend to be able to actualize themselves and direct themselves. Individuals' personalities and behaviors are unique, namely perceiving their environment, achieving something with all their potential, and are always expected to be completed.
Some [6] human being are as follows:

1) Humans grow through their experiences, either through feeling, thinking, awareness or discovery.

2) Life is the present life, and more than automatic behaviors determined by past events, the values of life are present rather than past or future.

3) Humans are emotional creatures, and essentially humans live in their person in a subjective world.

4) Familiarity with human relationships is one of the most ways a person can fulfill his needs.

5) Generally, every human being needs to be free, spontaneous, and communicate with each other.

6) Humans tend towards actualization, which is the tendency attached to the organism to develop its overall abilities in providing maintenance and enhancing self-actualization.

[10] Another one argued that:

1) The tendency to self-actualize is the primary defense motivation of the human organism.

2) The function of the whole organism.

3) A broad conception of motivation, including the fulfillment of needs and motives.

4) Life is an active process and has the capacity for selfactualization.

5) Humans are good, constructive or reliable, and become wise because of their intellectual abilities.

[11] The human ability to be able to actualize himself is rooted in four essential elements, namely:

1) Freedom refers to the fact that someone is a free agent and can choose.

2) Uniqueness, which means that humans differ from one another, cannot be equated to behavioristic theory.

3) Privacy directs individuals to understand that humanistic theory, especially on P.C., emphasizes each individual's subjective circumstances.

4) Self-transparency, clarity of the entire individual experience.

[12] Authors views that:

1) Every human being is in a world of experience that is constantly changing with its center.

2) The reactions of organisms to their environment as things that are experienced and accepted. This perceived field for the individual is a reality.

3) The organism's behavior is directed by the organism's efforts to get the satisfaction of its needs. 
4) Understanding the best behavior will only be obtained through or based on the individual's frame of reference.

5) The best way to adopt a behavior is based on consistency with his self-concept.

6) Self-defense behavior shows an inconsistency between organisms and self-concepts.

7) An optimal or fully functioning personal adjustment will only occur when the self-concept is congruent with the experience. The action is a tendency towards self-actualization, which is also the actualization of its self.

So, P.C. is built based on two hypotheses, namely (1) everyone can understand the circumstances that cause unhappiness and organize their life for the better, and (2) the child's ability to deal with this situation will occur and be improved if parents create a home environment with warmth, acceptance, and understand the relationship that is being built

[5] Certain attitudes in parents (sincerity, warmth, and non-positive acceptance, and accurate empathy) form the necessary and adequate conditions for effectiveness in childcare. P.C. incorporates the concept that the parent's function is direct and accessible to the child and focuses on the here and now experiences created through children's relationships.

The unique things in P.C. are:

1) This counseling is effective in several circumstances. P.C. helps improve social adjustment, psychological, learning, frustration tolerance, and reduce defensiveness. This approach is appropriate for treating mild to moderate anxiety, adjustment disorders, and conditions unrelated to mental disorders.

2) This counseling is beneficial for children who have problems fighting emotions and are becoming less and less affected over time by being fully aware of the feelings associated with the situation.

3) This counseling focuses on openness and relates to acceptance built by counselors and counselees, as well as short-term assistance processes.

4) The basis of this counseling only takes a relatively short time to learn.

5) This counseling has a positive view of human nature and continues to evolve.

So, the P.C. is not a set of models, nor is it a dogma. However, the P.C. Approach, which is rooted in the setting of attitudes and beliefs exhibited by parents, is perhaps best characterized as a way to exist and as a shared journey in which both parent and child demonstrate their humanity and participate in child's growth experience. Also, P.C. emphasizes children's experiences now and here, rather than focusing on problems during childhood and achieving new behaviour patterns in the future [13].

\subsection{Al-Qur'an perspective in understanding children's character}

The family has a critical role in the parenting process, although it is not the only factor determining the formation of a child's personality and abilities. [14] Theoretically, it can be said that in a good family (father and mother), children have the basics of growth and development that are strong enough to become adult humans. In the view of Islam, a good family is a peaceful family, which is the integration of love between husband and wife.

Childhood is a more difficult period of parenting. At this time, child development has reached a more sensitive level in many ways. Children have started to be introduced to their obligations through a fun approach. Both mothers and fathers are invited to give closer and concrete attention. Prophet Muhammad says since childhood, parents' efforts to practice life skills have been started, directing and instilling life in their future independence. Islam emphasizes once parents educate their children, they do not impose their humility. Still, it must be discussed [3] (Surah Asy-Syuura (42): 38 that "And (for) those who accept (obey) the call of their Lord and offer prayers, are their business. (It was decided) by deliberation between them and they spent part of the sustenance that we gave them ". And QS Al-Imran (3): 159) that" Then it is due to the grace of Allah that you are gentle towards them. Hard-hearted again harsh, of course, they distance themselves from around you. Therefore forgive them, ask forgiveness for them, and consult with them in that matter]. When you have made up your mind, then put your trust in Allah. Those who put their trust in Him.

So, in Islam, the primary measure of parental care for their children is the values contained in the Al-Qur'an and Sunnah. Because parents are always required to always direct according to the times, it indicates that parents' role in child care is crucial to shape the child's personality and develop academic potential through rational, religious, and moral. The parents' closeness to children is meaningful information compared to the influence given by other educational components. Prophet Muhammad says, "every child is born in a state of fitrah. It is the two parents who make him a Jew, a Christian, and a Magi. (Narrated by Bukhari and Muslim).

\subsection{The formation of children's character in Islamic view}

Whole human beings cannot be separated from the problem of education. Education for children is essential because humans are in the womb. Then they are born and grow into adults who are influenced by two environments, namely natural and social. Often the 
development and appearance of behavior are not good, resulting in incomplete human beings. Several forms of child development are developing aqidah, morals, worship, community mental, mental, physical, intellectual, health, and sexual ethics. Furthermore, [15] [16] [17] the most basic and primary education instilled in children is moral or character education because it is the source of everything. All life must run on ethical and moral values because there is no life without morals.

The ideal human being is a person who grows from childhood, above the moral requirements or after obtaining the values inherent from childhood. [18] [19] The child continues to grow and develop above the human and divine ethical requirements so that humans' noble qualities and virtues take root in the human self, mind, and soul.

According to Islam, the purpose of caring for children in the family is how a family helps develop children's potential to establish optimally. Later, they can carry out their caliphate duties on this earth, namely the ability of children to live in a society based on religious, moral values in a pluralistic, democratic society egalitarian without discrimination and exploitation. The same thing that must be known is that the duty of parents is the obligation to help or teach their children to always: (1) worship well, especially to pray five times a day, as a manifestation of faith and gratitude to Allah SWT, for the grace that has been given to him. (2) Doing good to parents is manifested in educational dialogues between parents and children so they understand what their rights and responsibilities are, [3] (3) does good and is close to fellow social partners without discriminatory treatment, meaning that children who can adapt themselves or carry themselves in a diverse society (Q.S. 49:13), and (4) can develop intellectual potential as a provision in understanding various problems, so that they can be useful for human life, and not destroy them. (Q.S. 30:41).

So, [20] [21] the educational process can run well if the environment created by parents and educators has complete, healthy, and balanced characteristics. Education or deeply religious life is a stable way of life so that it is not easily swayed by changing circumstances. The most important thing is the family environment, because children are born in the parents' territory, and all aspects of family life are simultaneously very influential on children. [22] Children need to be adequately guided at each stage of their development to show a complete unity of behaviour and lifestyle. This integrity can be observed from all expressions in the child's life, namely healthy children, healthy psychologically and physically, good children, avoiding lousy behavior or criminal behavior, and responsible children. [23] However, all of this will be realized if the family life, parents are harmonious, stable, prosperous, and happy. The spiritual life of parents and educators includes honesty, kindness, compassion, justice, and holiness.

\section{CONCLUSIONS}

Islam teaches that in caring for children not to differentiate between boys and girls, most aged or youngest children, normal or abnormal children, parents still provide the same opportunity to obtain educational services according to their potential, talents, and interest. Children must be treated fairly and not discriminatory. Warm parenting patterns, acceptance of each child's uniqueness, and the emphasis at this time and here are emphasized. In the Hadith of the Prophet Muhammad said, "Educate your children (girls and boys), not according to your wishes, because they are children of their time." (H.R. Ibnu Majah). Islamic education's concept to develop human beings is the formation of humans who have strong thinking power, skills that are beneficial to human benefit, and obey in carrying out Islamic law.

Along with the purpose of character education, this condition is the formation of humans with physical health, brilliant minds, stable and independent personalities, responsibility, and faith, and fear of Allah, Swt. Because humans are good, have a positive character, move forward, constructive, realistic, and reliable, and everyone is aware, focused, and advancing towards selfactualization from childhood. According to Roger, selfactualization is the most common driver, and motivating existence includes actions that affect the person as a whole.

\section{AUTHOR'S CONTRIBUTIONS}

Siti Rahmi conceived and designed the research proposal and instrument. She also collected the data, performed the data analysis, and wrote the paper.

Urotul Aliyah contributed to conceiving and designing the research proposal and instrument. She also collected the data and wrote the paper.

Nurul Fadilah collected the data, performed the data analysis, and contributed to writing the paper.

\section{ACKNOWLEDGMENTS}

This article would not have been possible without various parties' support, especially we are very grateful to Dr. Suyadi, M.Pd, as Dean of Faculty Teaching Training and Education of the University of Borneo Tarakan. He has provided support and opportunities for us in this research. And we also thank the extended family of the Nurul Amaliah Mushola at Gunung Lingkas and all those who have worked with us during this research process, which we cannot name one by one. 


\section{REFERENCES}

[1] E. S. Cahyaningrum, S. Sudaryanti and N. . A. Purwanto, "Pengembangan Nilai-Nilai Karakter Anak Usia Dini Melalui Pembiasaan dan Keteladanan," Jurnal Pendidikan Anak, vol. 6, no. 2, pp. 203-213, 2017.

[2] A. Amini, S. Y. Yurnita and H. Hasnidar, "The Development of Character Education Model trough an Integrated Curriculum at Elementary Education Level in Medan City," International Journal on Language, Research and Education Studies, vol. 1, no. 2, pp. 298-311, 2017.

[3] K. A. R. Indonesia, Al-Qr'anul Karim, Banyuianyar: Zyyad Books, 2014.

[4] G. Corey, Theory And Practice Of Counseling And Psycoteraphy, 2nd Edition ed., California: Brooks/Cole publisher Company, 1982.

[5] G. Corey, Theory and Practice of Counseling and Psychotherapy, Enhanced, 10th Edition ed., Boston: Cengage Learning, 2017.

[6] R. L. Gibson, Introduction To Counseling And Guidance, 7th Edition ed., New Delhi: PrenticeHall Of India Pvt. Limited, 2008.

[7] C. R. Lochmiller and J. N. Lester, An Introduction to Educational Research: Connecting Methods to Practice, California: SAGE Publications, Inc, 2017.

[8] . S. K. Grove and J. R. Gray, Understanding Nursing Research: Building an Evidance-Based Practice, First South Asia Edition ed., New Delhi: Elsevier, Inc, 2019.

[9] D. Knox, C. Schacht and I. J. Chang, Choices in Relationships, 13th Edition ed., Singapore: SAGE Publications, 2019.

[10] Willis, Konseling Individual, Teori dan Praktek, Bandung: Alfabeta, 2015.

[11] S. Soedarmadji and H. Hartono, Psikologi Konseling, Jakarta: Prenadamedia, 2015.

[12] G. Komalasari, E. Wahyuni and . K. Karsih, Teori dan teknik konseling, Jakarta : Indeks, 2011.

[13] M. Mulawarman, E. P. Nugraheni, . A. Putri and T. Febrianti, Psikologi Konseling: Sebuah Pengantar
Bagi Konselor Pendidikan, Jakarta: Prenada Media, 2020.

[14] M. Surya, Bina Keluarga, Semarang: Aneka Ilmu, 2003.

[15] H. C. A. Kistoro, . C. Setiawan, E. Latipah and H. Putranta, "Teacher's Experiences in Character Education for Autistic," International Journal of Evaluation and Research in Education, vol. 10, no. 1, pp. 65-77, 2021.

[16] S. N. Z. Niswah, A. W. Pudjastawa and S. Endraswara, "Moral Teaching in Piwulang Manuscript and Its Relevance to The Teaching of Character Education in Indonesia," in The 1st International Conference on Character Education, Semarang, 2020.

[17] T. Triyanto and T. Rejekiningsih, "Building Tolerance Character for Students in the Digital Era," in The 1st International Conference on Character Education, Semarang, 2020.

[18] S. Tao, A. Peng and X. Chen, "“Being So Caught up": Exploring Religious Projection and Ethical Appeal in Leda and the Swan," Religion Journal, vol. 12 , no. 2, pp. 1-21, 2021

[19] "Self Actualization According to Bediuzaman Said Nursi (1877-1960) in Risale-I Nur," Psychology and Education, vol. 58, no. 2, pp. 141-153, 2021.

[20] J. Obrovská and K. S. Janků, "Resilience capacity and supportive factors of compulsory education in ethnic minority families: mixed methods study of Czech Roma mothers," Contemporary Social Science, 2021.

[21] N. M. Ardoina and A. W. Bowersb, "Early childhood environmental education: A systematic review of the research literature," Educational Research Review, vol. 31, 2020.

[22] M. I. Llanos, L. A. Zapardiel and C. Rodríguez, "Children's first manifestations of cognitive control in the early years school: the importance of the educational situation and materiality," European Journal of Psychology of Education, 2020.

[23] A. Trisiana, "A New Paradigm of Character Education During Covid-19 Pandemic: Comparative Analysis Towards Digital Revolution," in The 1st International Conference on Character Education, Semarang, 2020. 